НАУКОВИЙ ВІСНИК онального универеитит

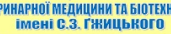
Scientific messenger r f L wiv National University
Veterinary Medicine and Biotechnologics

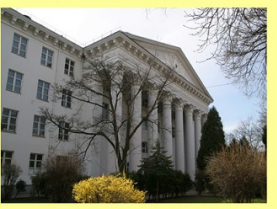

СЕРІЯ “ЕКОНОМІЧН НАУКІ

Том 23 № 98

2021
Науковий вісник Дьвівського національного університету ветеринарної медицини та біотехнологій імені С.3. Гжицького. Серія: Економічні науки

\author{
Scientific Messenger of Lviv National University \\ of Veterinary Medicine and Biotechnologies. \\ Series: Economical Sciences
}

ISSN 2519-2701 print

https://nvlvet.com.ua/index.php/economy

doi: $10.32718 /$ nvlvet-e9807

UDC 332.3

\title{
Land taxation as a tool to ensure sustainable development of rural areas in the context of decentralization
}

\author{
N. Khomiuk ${ }^{1}$, I. Tsymbaliuk ${ }^{1}$, M. Voichuk ${ }^{1}$, A. Grymak ${ }^{2}$, I. Kravtsiv ${ }^{2}$ \\ ${ }^{1}$ Lesya Ukrainka Volyn national university, Lutsk, Ukraine \\ ${ }^{2}$ Stepan Gzhytskyi National University of Veterinary Medicine and Biotechnologies Lviv, Lviv, Ukraine
}

\section{Article info}

Received 17.10.2021

Received in revised form 22.11 .2020

Accepted 23.11.2021

Lesya Ukrainka Volyn national university, Lutsk

Voli avenue, 13, Lutsk,

43025 , Ukraine.

Tel.: +38-050-500-89-25

E-mail:nataljabilous@gmail.com

Stepan Gzhytskyi National University of Veterinary Medicine and Biotechnologies Lviv,

Pekarska Str. 50, Lviv,

79010, Ukraine.
Khomiuk, N., Tsymbaliuk, I., Voichuk, M., Grymak, A., \& Kravtsiv, I. (2021). Land taxation as a tool to ensure sustainable development of rural areas in the context of decentralization. Scientific Messenger of Lviv National University of Veterinary Medicine and Biotechnologies. Series: Economical Sciences, 23 (98), 45-51. doi: 10.32718/nvlvet-e9807

The article considers land taxation as one of the tools to ensure the sustainable development of rural areas in the context of decentralization. Included land tax and rent for land plots of state and communal property and a single tax for agricultural producers as land tax payments has been proposed. It was found that the land fee is the second-largest source of tax revenues to local budgets. It was revealed that during 2009-2020 there is a tendency to increase revenues from land fees to local budgets of Ukraine. Emphasis is placed on the fact that there is an increase in rent payments by legal entities and individuals in parallel with a decrease in its share in the payment for land, which is caused by an increase in land tax revenues during the analyzed period by 4.5 times. It was found that the largest amounts of revenues from land fees are payments from legal entities (86-88\% of the total revenues). It was found that the number of revenues from land tax and rent for land plots of state and communal property paid by individuals increased 4.5 times, and the number of revenues from similar taxes from legal entities increased 3.6 times. As a result of the study, attention is focused on the fact that since 2015 the payment for land has been transferred from the status of a national tax to a local one. It is proved that to tax the regulation of agricultural land use and promotes the development of agriculture and rural areas in 1998, a fixed agricultural tax was introduced. It was found that the number of receipts of the single tax paid by agricultural producers in 2015 increased 17 times compared to 2014. The sharp increase is caused by the introduction of the annual indexation of the tax base for agricultural enterprises, and a threefold increase in tax rates is justified. To achieve the goals of sustainable development of rural areas, it is proposed to carry out such measures as the application of increasing coefficients for irrational use of agricultural lands, provision of benefits for organic agricultural producers, implementation of the full inventory of agricultural lands, improvement of normative monetary valuation of land use for land and/or the single tax of the fourth group for the implementation of measures for the protection and reproduction of land resources, which will increase employment in rural areas, overcome poverty, develop social infrastructure, ensure the livelihood of rural residents, food, economic and environmental security, reduce destructive effects on the environment, protection and reproduction of natural resource potential.

Key words: land taxation, land payment, sustainable development, rural areas, rent, single tax.

\section{Земельне оподаткування як інструмент забезпечення сталого розвитку сільських територій в умовах децентралізації}

\author{
Н. Л. Хомюк ${ }^{1}$, І. О. Цимбалюк ${ }^{1}$, М. В. Войчук ${ }^{1}$, А. В. Гримак ${ }^{2}$, І. К. Кравців ${ }^{2}$ \\ ${ }^{1}$ Волинський начіональний університет імені Лесі Украӥнки, Луцьк, Украӥна \\ ${ }^{2}$ Львівський наиіональний університет ветеринарної медицини та біотехнологій імені С. 3. Гюицького, м. Львів, \\ Україна
}


У статті розглянуто земельне оподаткування як один із інструментів забезпечення сталого розвитку сільських територій в умовах децентралізації. Запропоновано до земельних податкових платежів віднести земельний податок та орендну плату за земельні ділянки державної та комунальної власності та єдиний податок для сільськогосподарських товаровиробників. Виявлено, щуо плата за землю є другим за обсягом джерело податкових надходжень до місиевих бюджетів. Виявлено, ияо впродовж 20092020 рр. спостерігається тендениія зростання надходжень плати за землю до місиевих бюджетів Украӥни. Акиентовано увагу на тому, що спостерігається збільшення обсягів сплати орендної плати юридичними та фізичними особами паралельно зі зменшенням ї̈ частки у складі плати за землю, щчо спричинено збільшенням надходжень до бюджетів земельного податку впродовж аналізованого періоду у 4,5 рази. Виявлено, щуо найбільші обсяги надходжень плати за землю становлять платежі від юридичних осіб (86-88\% від загальної суми надходжень). Виявлено, щзо обсяги надходжень земельного податку та орендної плати за земельні ділянки державної та комунальної власності, сплачених фізичними особами, зросли у 4,5 рази, а розмір надходжень аналогічних податків від юридччних осіб - у 3,6 рази. В результаті дослідження акиентовано увагу на тому, щзо з 2015 р. плату за землю переведено із статусу загальнодержавного податку у місцевий. Доведено, щуо з метою податкового регулювання сільськогосподарського землекористування та сприяння розвитку сільського господарства й сільських територій у 1998 р. введено фіксований сільськогосподарський податок. Виявлено, шуо сума надходжень єдиного податку, сплаченого сільськогосподарськими товаровиробниками, у 2015 р. зросла у 17 разів, порівняно з 2014 р. Обтрунтовано, щуо різке зростання спричинене запровадженням шорічної індексаиї бази оподаткування для сільгосппідприємств та збільшенням втричі ставок податку. Запропоновано для досягнення цілей сталого розвитку сільських територій проведення таких заходів, як: застосування підвищувальних коефіцієнтів за нераціональне використання земель сільськогосподарського призначення, надання пільг для органічних сільськогосподарських товаровиробників, здійснення повної інвентаризації земель сільськогосподарського призначення, вдосконалення нормативної грошової оцінки земель, забезпечення иільового використання надходжень від плати за землю та/або єдиного податку четвертої групи на здійснення заходів з охорони та відтворення земельних ресурсів, шуо сприятиме підвищенню рівня зайнятості на селі, подоланню бідності, розвитку сочіальної інфраструктури, забезпеченню життєдіяльності сільських жителів, дотриманню продовольчої, економічної та екологічної безпеки, зменшенню деструктивного впливу на довкілля, охороні та відтворенню природоресурсного потениіалу.

Ключові слова: земельне оподаткування, плата за землю, сталий розвиток, сільські території, орендна плата, єдиний податок

\section{Вступ}

Однією із Цілей сталого розвитку є подолання голоду, що передбачає стимулювання сталих методів ведення сільського господарства: підтримку дрібних фермерів і забезпечення рівноправного доступу до землі, технологій і ринків (UNDP Ukraine, 2020). Підтримка фермерів можлива не лише через надання пільгових кредитів, а й через пільгове земельне оподаткування. Доцільно відмітити, що в Україні, відповідно до Цілі 11 сталого розвитку особливу увагу приділяється відкритості, безпеці й екологічній стійкості міст та спільнот. Майже 90 \% від загальної площі країни займають сільські території, де проживає третина усього населення (Khomiuk et al., 2020). Тому Ціль 15 сталого розвитку щодо збереження екосистем суші тісно взаємопов'язана із забезпеченням сталого розвитку сільських територій, адже спрямована на збереження і відновлення використання наземних екосистем, таких як ліси, водно-болотні угіддя, посушливі землі та гори. Тому доцільно обгрунтувати інструменти, які б сприяли зростанню доходів сільського населення, зменшенню рівня безробіття на селі, досягненню продовольчої та екологічної безпеки, раціональному використанню, охороні та відтворенню природних (водних, земельних) ресурсів, що життєво важливо для пом'якшення наслідків кліматичних змін.

Проблематику процесів сталого розвитку сільських територій відображено в дослідженнях таких науковців, як О. Бородіна, М. Долішній, Ю. Лупенко (Lupenko, 2015), А. Малиновський, О. Онищенко, О. Павлов, Х. Притула, О. Попова, I. Прокопа, О. Шубравська, М. Хвесик, В. Юрчишин й ін. Звернемо увагу на те, що попри вагомий теоретичний i прикладний здобуток учених із зазначеної тематики, потребують дослідження інструменти забезпечення сталого розвитку сільських територій.
Метою дослідження є обгрунтування земельного оподаткування як одного із інструментів забезпечення сталого розвитку сільських територій в умовах децентралізації.

Для досягнення поставленої мети вирішуються наступні завдання: розкрити сутність поняття «сталий розвиток сільських територій», виконати оцінку надходжень плати за землю та єдиного податку для сільськогосподарських товаровиробників до місцевих бюджетів України; обгрунтувати значення земельного оподаткування для досягнення цілей сталого розвитку сільських територій.

\section{Матеріал і методи досліджень}

У процесі дослідження застосовувалися загальноприйняті в економічній науці методи: монографічний - при теоретичному обгрунтуванні поняття “сталий розвиток сільських територій”; економікостатистичний, графічний - при оцінці надходжень плати за землю, фіксованого сільськогосподарського податку та єдиного податку четвертої групи до місцевих бюджетів України, наукового узагальнення - при обгрунтуванні земельного оподаткування як економічного інструменту забезпечення сталого розвитку сільських територій.

Інформаційною базою дослідження слугували статичні дані Державної казначейської служби України, наукові праці вітчизняних і зарубіжних авторів, електронні ресурси, представлені в мережі Інтернет, результати власних досліджень авторів тощо.

\section{Результати та їх обговорення}

Сталий розвиток сільських територій, на думку В. Загорського та Є. Борщука, повинен відбуватися “на основі модернізації виробничої інфраструктури, підвищення рівня зайнятості сільського населення, зме- 
ншення трудової міграції, підвищення конкурентоспроможності сільськогосподарського виробництва, покращення якості і безпеки сільськогосподарської продукції, поліпшення екологічної ситуації у сільській місцевості та забезпечення високого рівня відтворення природних ресурсів. Йому необхідна наявність зваженого підходу до державного регулювання розвитку сільських територій, із урахуванням їх особливостей, $з$ метою створення умов для саморозвитку та активізації людського потенціалу" (Zahorskyi \& Borshchuk, 2019).

Залучення інвестицій у сталий розвиток сільських територій із врахуванням регіональних особливостей сприятиме створенню робочих місць, зростанню доходів сільських жителів, відродженню місцевих народних промислів, звичаїв та ремесл, покращенню благоустрою сіл і зміні свідомості сільських жителів (Khomiuk et al., 2020).

Для розвитку сільського господарства, сільських територій найбільшого значення мають технічний прогрес, розвиток підприємництва, динамічність факторів сільськогосподарського розвитку, загальний економічний ріст, політичне сприяння. Потрібно переглянути й сформувати таку правову базу, яка б захищала інтереси сільськогосподарських виробників; створити умови ефективного розвитку аграрного сектору; сформувати сприятливу систему оподаткування (Tsymbaliuk \& Rykovska, 2017).

Одним із економічних інструментів забезпечення сталого розвитку сільських територій в умовах децентралізації, на нашу думку, є земельне оподаткування. До земельних податкових платежів варто віднести земельний податок й орендну плату за земельні ділянки державної та комунальної власності у складі плати за землю і єдиний податок для сільськогосподарських товаровиробників, адже об'єктом оподаткування виступає площа сільськогосподарських угідь.

Плата за землю - друге за обсягом (після податку 3 доходів фізичних осіб) джерело податкових надходжень до бюджетів новосформованих територіальних громад. На рис. 1 відображено обсяги надходжень плати за землю до Зведеного бюджету України впродовж 1992-2020 pp.

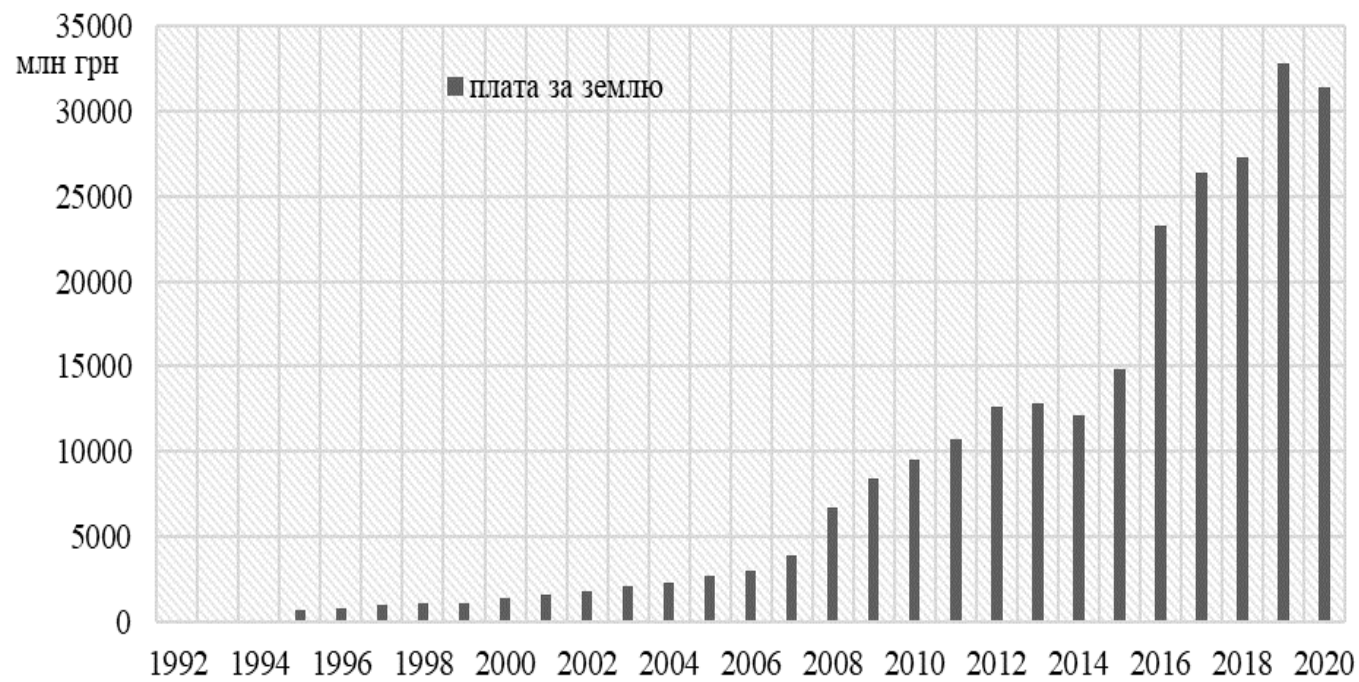

Рис. 1. Обсяги надходжень плати за землю до Зведеного бюджету України Джерело: побудовано авторами на основі даних (Derzhavna kaznacheiska sluzhba Ukrainy, 2021)

В таблиці 1 відображено обсяги надходження плати за землю до місцевих бюджетів України у розрізі іiі складових, таких як: земельний податок з юридичних і фізичних осіб й орендна плата з юридичних і фізичних осіб впродовж 2014-2020 рр. Слід відмітити, що фактичні обсяги надходжень земельного податку з юридичних осіб зросли від 2776,4 млнгрн у 2014 р. до
10828,9 млн грн у 2020 р.; земельного податку з фізичних осіб - від 384,9 млн грн у 2009 р. до 1984,8 млн грн у 2020 р. Аналогічно збільшились фактичні обсяги надходжень орендної плати 3 юридичних осіб від 7819,7 млн грн у 2014 р. до 16369,4 млн грн у 2020 р. та орендної плати 3 фізичних осіб - від 1102,9 млн грн у 2014 р. до 2288,7 млн грн у 2020 р.

\section{Таблиця 1}

Фактичні обсяги надходжень плати за землю до місцевих бюджетів України

\begin{tabular}{lccccccc}
\hline \multicolumn{1}{c}{ Показник, } \\
\multicolumn{1}{c}{ млн грн } & 2014 рік & 2015 рік & \multirow{2}{*}{2016 рік } & \multirow{2}{*}{2017 рік } & 2018 рік & 2019 рік & 2020 рік \\
\hline Плата за землю & 12083,9 & 14831,5 & 23323,7 & 26384,5 & 27321,1 & 32835,6 & 31471,8 \\
Земельний податок з юридичних осіб & 2776,4 & 3558,8 & 7061 & 8262,3 & 8241,2 & 11488,7 & 10828,9 \\
Орендна плата з юридичних осіб & 7819,7 & 9413,9 & 13351,5 & 14701,6 & 15288,1 & 17193,5 & 16369,4 \\
Земельний податок з фізичних осіб & 384,9 & 501,1 & 1032,3 & 1387,4 & 1629,4 & 1860,9 & 1984,8 \\
Орендна плата 3 фізичних осіб & 1102,9 & 1357,7 & 1878,9 & 2033,2 & 2162,4 & 2292,5 & 2288,7 \\
\hline
\end{tabular}

Джерело: узагальнено авторами на основі даних (Derzhavna kaznacheiska sluzhba Ukrainy, 2021) 
Як бачимо з таблиці 2, впродовж аналізованого періоду спостерігається тенденція зростання надходжень плати за землю до місцевих бюджетів України. Хоча у 2020 р. у зв'язку з економічною і політичною ситуацією, пандемією COVID-19 сума надходжень, в порівнянні 3
2019 р., зменшилась на 1363,8 млн грн, 3 них земельний податок з юридичних осіб - на 659,8 млн грн, а орендна плата 3 юридичних осіб - на 824,1 млн грн. Впродовж 2014-2020 рр. фактичні обсяги надходжень плати за землю збільшились на 19387,9 млн грн.

Таблиця 2

Абсолютні відхилення надходжень плати за землю

\begin{tabular}{lccccccc}
\hline \multirow{2}{*}{$\begin{array}{c}\text { Показник, } \\
\text { млн грн }\end{array}$} & \multicolumn{7}{c}{ Абсолютні відхилення, млн грн } \\
\cline { 2 - 7 } & $2020-$ & $2019-$ & $2018-$ & $2017-$ & $2016-$ & $2015-$ & $2020-$ \\
Плата за землю & 2019 pp. & 2018 pp. & 2017 pp. & 2016 pp. & 2015 pp. & 2014 pp. & 2014 pp. \\
Земельний податок з юридичних осіб & $-1363,8$ & 5514,5 & 936,6 & 3060,8 & 8492,2 & 2747,6 & 19387,9 \\
Орендна плата з юридичних осіб & $-659,8$ & 3247,5 & $-21,1$ & 1201,3 & 3502,2 & 782,4 & 8052,5 \\
Земельний податок з фізичних осіб & $-824,1$ & 1905,4 & 586,5 & 1350,1 & 3937,6 & 1594,2 & 8549,7 \\
Орендна плата 3 фізичних осіб & 123,9 & 231,5 & 242 & 355,1 & 531,2 & 116,2 & 1599,9 \\
\hline
\end{tabular}

Джерело: розраховано авторами на основі даних (Derzhavna kaznacheiska sluzhba Ukrainy, 2021)

Структура плати за землю впродовж 2009-2020 pp. відповідно також зазнала змін, що відображено на рис. 2. Частка земельного податку, сплаченого юридичними та фізичними особами, у 2009 р. займала 33,7 \% від загального обсягу фактичних надходжень плати за землю до Зведеного бюджету України. У 2014 р. цей показник знизився до $26,2 \%$, а у 2020 р., навпаки, - зріс до 40,7 \%, що спричинене змінами у Податковому кодексі України щодо затвердження розмірів ставок податку місцевими органами влади.

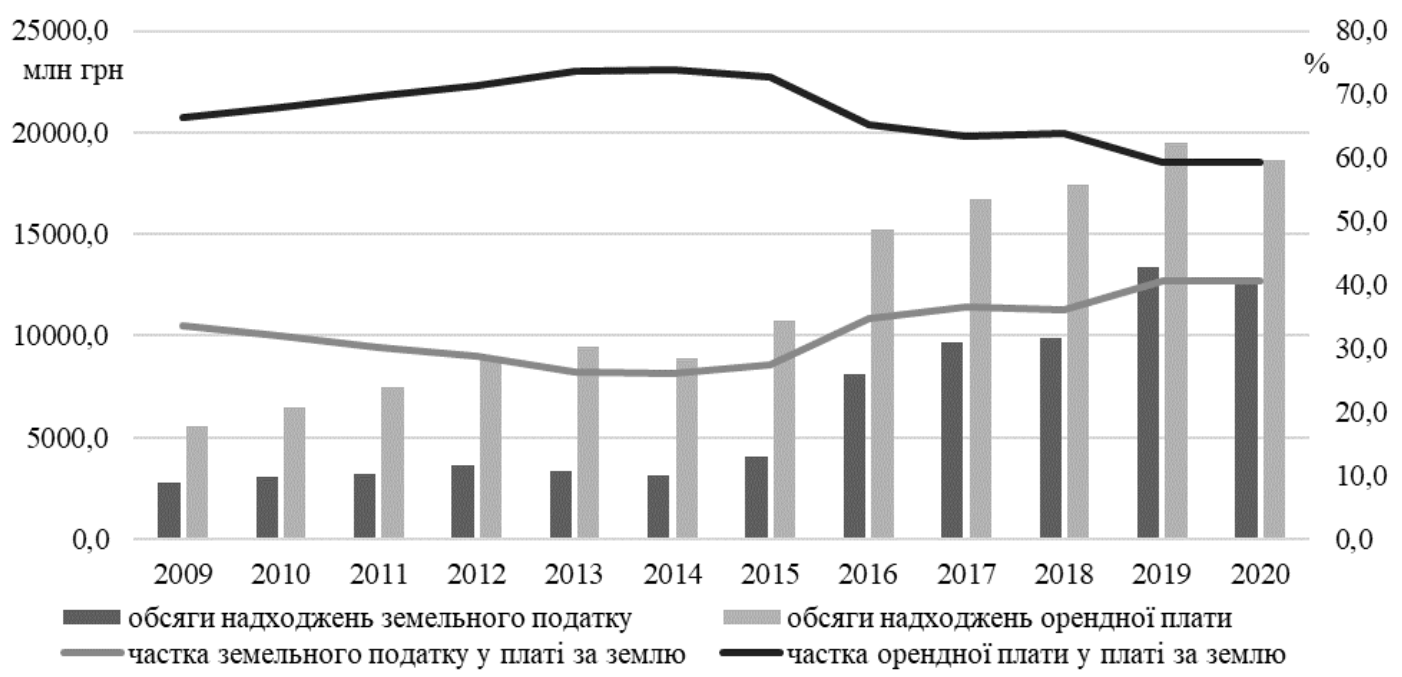

Рис. 2. Обсяги надходжень земельного податку та орендної плати та структура плати за землю Джерело: побудовано авторами на основі даних (Derzhavna kaznacheiska sluzhba Ukrainy, 2021)

Спостерігаємо збільшення обсягів сплати орендної плати юридичними та фізичними особами 3 5547,8 млн грн у 2009 р. до 18658,1 млн грн у 2020 р., проте іiі частка зменшилась з 66,3 \% у 2009 р. до 59,3 \% у 2020 р., що спричинено збільшенням надходжень до бюджетів земельного податку впродовж аналізованого періоду у 4,5 рази. На рис. 3 відображено структуру плати за землю у розрізі контрагентів. Найбільші обсяги сплати земельного податку та орендної плати за земельні ділянки державної та комуна- льної власності становлять платежі від юридичних осіб, а це приблизно 86-88 \% від загальної суми надходжень. Структура плати за землю у розрізі платників податку не зазнала значних змін, проте зросли обсяги надходжень земельного податку та орендної плати за земельні ділянки державної та комунальної власності, сплачених фізичними особами, у 4,5 рази, а розмір надходжень аналогічних податків від юридичних осіб - у 3,6 рази. 


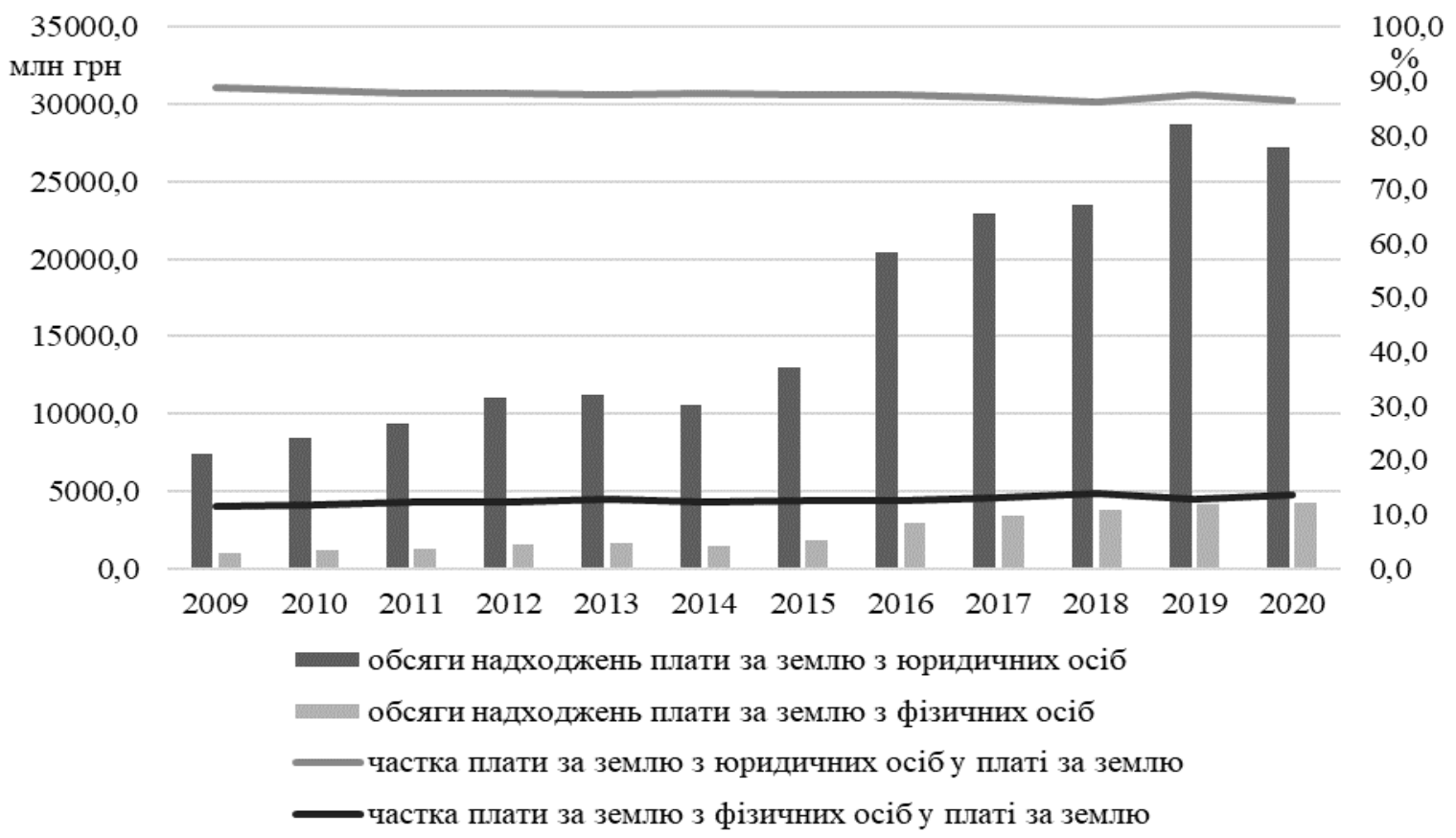

Рис. 3. Обсяги сплати та структура плати за землю в розрізі контрагентів Джерело: побудовано авторами на основі даних (Derzhavna kaznacheiska sluzhba Ukrainy, 2021)

В розрізі квартальних надходжень земельних податкових платежів спостерігається динаміка зростання обсягів плати за землю (рис. 4). Впродовж 2020 р. до місцевих бюджетів України сплачено 31471,8 млн грн, що на 23109,1 млн грн більше, ніж у 2009 році. У зв'язку зі змінами у податковому та бюджетному законодавстві, а саме прийняття Бюджетно- го кодексу України (8 липня 2010 р.) та Податкового кодексу України (2 грудня 2010 р.), плата за землю почала зараховуватися повністю до місцевих бюджетів, адже до 2010 р. даний платіж розподілявся у відсотковому відношенні до обласних та районних бюджетів.

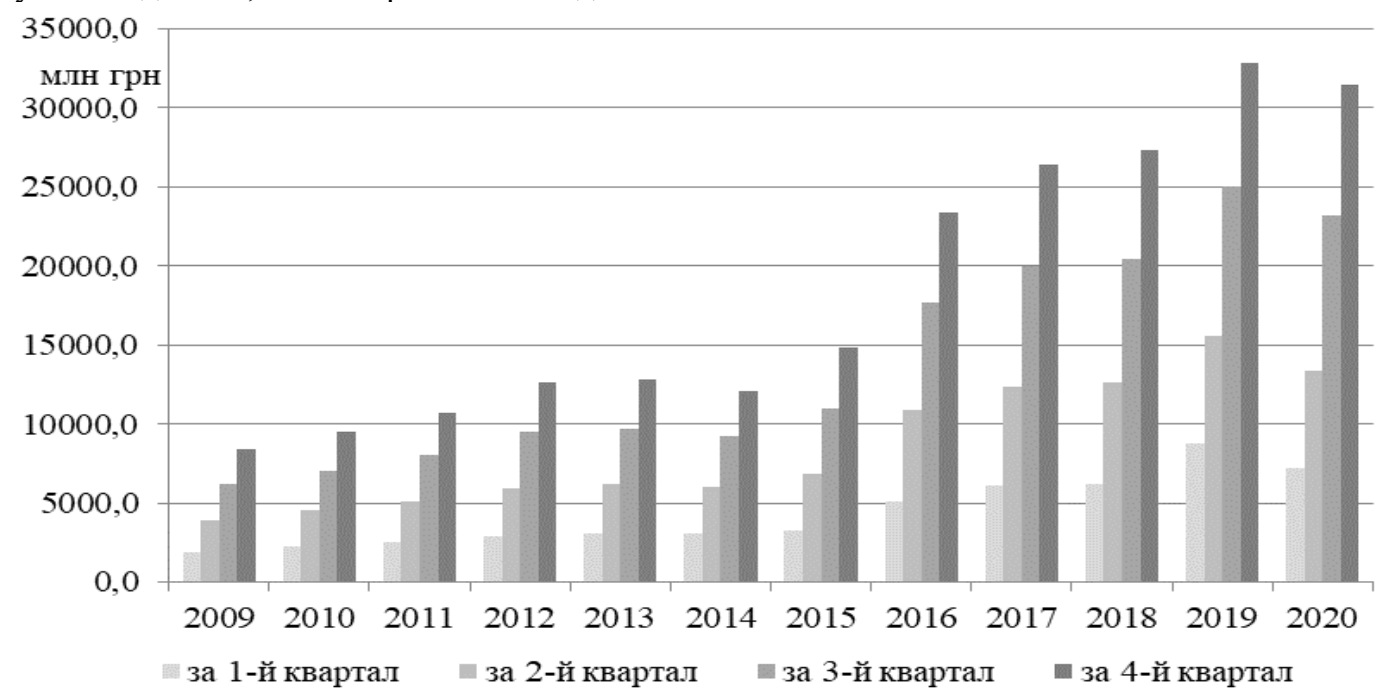

Рис. 4. Динаміка надходжень плати за землю до Зведеного та місцевих бюджетів України Джерело: побудовано авторами на основі даних (Derzhavna kaznacheiska sluzhba Ukrainy, 2021)

Закон України "Про внесення змін до Податкового кодексу України та деяких законодавчих актів України щодо податкової реформи” від 28.12.2014 р № 71VIII виправив дисонанс у законодавстві, тобто перевів плату за землю із статусу загальнодержавного податку у місцевий, що дало можливість краще розподіляти кошти на рівні громад (Pavlikha \& Khomiuk, 2017). Ці заходи мали важливе значення, оскільки в державі був уже прийнятий курс на децентралізацію.
3 метою податкового регулювання сільськогосподарського землекористування та сприяння розвитку сільського господарства й сільських територій у 1998 р. введено фіксований сільськогосподарський податок. Обсяги надходжень фіксованого сільськогосподарського податку впродовж 2009-2014 pp. не змінювалися і становили близько 100 млн грн на рік (рис. 5) (Khomiuk, 2019). 


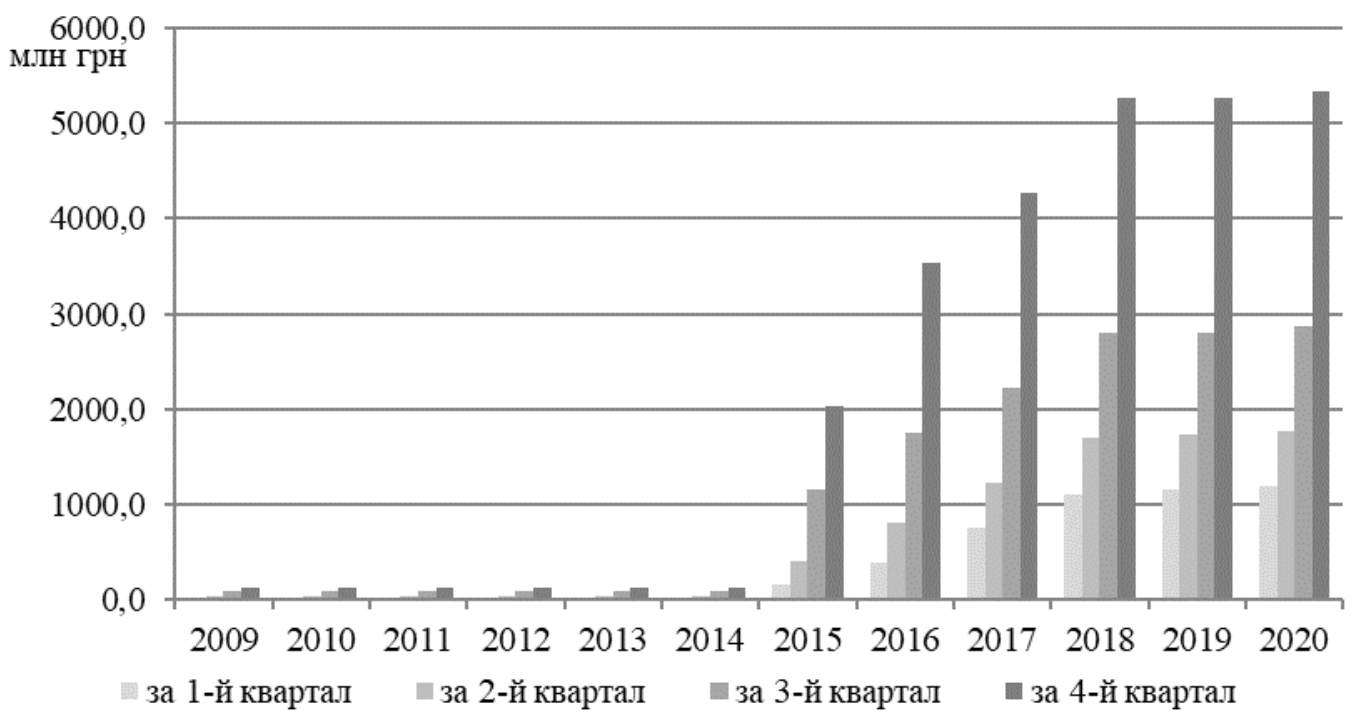

Рис. 5. Динаміка надходжень єдиного податку четвертої групи (раніше ФСП) до місцевих бюджетів України Джерело: побудовано авторами на основі даних (Derzhavna kaznacheiska sluzhba Ukrainy, 2021)

32015 р. фіксований сільськогосподарський податок перейменовано в єдиний податок четвертої групи. Сума надходжень даного податку, сплаченого сільськогосподарськими товаровиробниками, у 2015 р. зросла у 17 разів і становила 2024,2 млн грн. Різке зростання спричинене запровадженням щорічної індексації бази оподаткування для сільгосппідприємств та збільшенням ставок податку втричі (Khomiuk, 2019). Наприклад, у 2014 р. середній розмір фіксованого сільськогосподарського податку 3 одного гектара сількогосподарських угідь складав близько 6 грн/га, а з 2015 р. середній розмір єдиного податку став перевищувати 115 грн/га, що дозволило збільшити надходження до місцевих бюджетів (Khomiuk, 2019).

Забезпечення сталого розвитку сільських територій повинно грунтуватися на засадах єдності й цілісності $з$ обов'язковим врахуванням географічних, економічних, екологічних, етнічних та демографічних особливостей сільських територій, на яких здійснюється діяльність агровиробників (Khomiuk, 2020).

Ю. Лупенко зазначає, що податкове навантаження на сільськогосподарські підприємства у рамках застосування спрощеної системи оподаткування, яка почала діяти 31 січня 2015 р., не перевищує відповідних показників по інших системах оподаткування - спрощеної (від доходу) та загальної (від прибутку). Він вважає, що навантаження, враховуючи фактичну доходність агробізнесу в останні роки, не повинно стани критичним для даної галузі (Lupenko, 2015).

На думку В. Голяна та В. Бардась, вищі ставки земельних податкових платежів сприятимуть тому, що “землекористувач максимальною мірою буде використовувати внутрішні резерви та зовнішні запозичення для впровадження інноваційних технологій, оскільки це був би єдиний шлях закріпитися на ринку та отримати конкурентні переваги" (Holian \& Bardas, 2011).

Інші науковці зазначають, що збільшення ставок єдиного податку змушує підприємців скорочувати витрати на виробництво, а саме: впровадження новітніх технологій, раціональне використання ресурсів
(Karlin et al., 2018) Як бачимо, зростання абсолютних показників обсягу податкових надходжень до бюджетів пов'язане із інфляційним чинником та падінням курсу національної валюти, так і частково із позитивними змінами в організації податкової сфери, зокрема адміністрування податків (Tsymbaliuk, 2019).

\section{Висновки}

3 метою забезпечення сталого розвитку сільських територій та стимулювання ефективного використання земельних ресурсів необхідним $є$ проведення низки заходів, серед яких: застосування підвищувальних коефіцієнтів за нераціональне використання земель сільськогосподарського призначення, надання пільг для органічних сільськогосподарських товаровиробників, здійснення повної інвентаризації земель сільськогосподарського призначення, вдосконалення нормативної грошової оцінки земель, забезпечення цільового використання надходжень від плати за землю та/або єдиного податку четвертої групи на здійснення заходів з охорони та відтворення земельних ресурсів, що сприятиме підвищенню рівня зайнятості на селі, подоланню бідності, розвитку соціальної інфраструктури, забезпеченню життєдіяльності сільських жителів, дотриманню продовольчої, економічної та екологічної безпеки, зменшенню деструктивного впливу на довкілля, охороні та відтворенню природоресурсного потенціалу.

Перспективи подальших досліджень. Подальші дослідження проводитимуться щодо визначення ролі земельного податку та орендної плати в системі регіонального землекористування 3 метою забезпечення фінансування потреб місцевих громад.

\section{References}

Derzhavna kaznacheiska sluzhba Ukrainy: ofits. veb-sait: ukrain. versiia. URL: http://www.treasury.gov.ua (data zvernennia: 07.10.2021) (in Ukrainian). 
Holian, V., \& Bardas, V. (2011). Udoskonalennia systemy fiskalnoho rehuliuvannia pryrodokorystuvannia: dominanty podolannia syndromu "symvolichnosti" normatyviv platy. Formuvannia rynkovykh vidnosyn $\mathrm{v}$ Ukraini, 11，145-151. URL: http://nbuv.gov.ua/UJRN/ frvu_2011_11_31 (data zvernennia: 07.10.2021) (in Ukrainian).

Karlin, M. I., Tsymbaliuk, I. O., \& Prots, N. V. (2018). Features tax reform and mechanism of hiding taxes in Ukraine. Financial and Credit Activity: Problems of Theory and Practice, 1(24), 123-130. doi: $10.18371 /$ fcaptp.v1i24.128327.

Khomiuk, N. (2019). Improving the taxation system of Ukrainian farming. International Journal of New Economics, Public Administration and Law, 2(2), 1727. doi:10.31264/2545-093X-2019-2(4)-17-27.

Khomiuk, N. L. (2019). Dynamika spravliannia ta nadkhodzhennia zemelnykh platezhiv $\mathrm{v}$ tradytsiinomu ta orhanichnomu silskohospodarskomu zemlekorystuvanni v Ukraini. Zbalansovane pryrodokorystuvannia, 2, 201213. doi: $10.33730 / 2310-4678.2 .2019 .184207$ (in Ukrainian).

Khomiuk, N. L. (2020). Metodolohichnyi bazys doslidzhennia dyversyfikatsii rozvytku silskykh terytorii v umovakh detsentralizatsii. Prychornomorski ekonomichni studii, 50(2), 80-84. doi:10.32843/bses.50-45 (in Ukrainian).

Khomiuk, N., Bochko, O., Pavlikha, N., Demchuk, A., Stashchuk, O., Shmatkovska, T., \& Naumenko, N. (2020). Economic modeling of sustainable rural development under the conditions of decentralization: a case study of Ukraine. Scientific Papers. Series: Management, Economic Engineering in Agriculture and Rural Development, 20(3), 317-332. URL: http://managementjournal.usamv.ro/pdf/vol.20 3/Art3 7.pdf (data zvernennia: 07.10.2021).

Khomiuk, N., Pavlikha, N., \& Voronyj I. (2020). Diversification as a tool for sustainable development of rural areas in the context of decentralization. Scientific
Messenger of Lviv National University of Veterinary Medicine and Biotechnologies. Series: Economical Sciences, 22(96), 35-41. doi:10.32718/nvlvet-e9606 (in Ukrainian).

Lupenko, Yu. (2015) Epokha fiksovanoho silskohospodarskoho podatku skinchylasia. V diiu vstupaiut novi pravyla. URL: http://www.iae.org.ua/ presscentre/archnews/1093-2015-01-13-12-47-50.html (data zvernennia: 07.10.2021) (in Ukrainian).

Pavlikha, N. V., \& Khomiuk, N. L. (2017). Transformatsiia systemy platezhiv za korystuvannia zemliamy silskohospodarskoho pryznachennia: monograph. Lutsk. URL: https:/evnuir.vnu.edu.ua/handle/123456789/ 13162? mode=full (data zvernennia: 07.10.2021) (in Ukrainian).

Sustainable development goals 2015-2030. UNDP Ukraine: ofits. veb-sait: ukrain. versiia. URL: https:/www.ua.undp.org/content/ukraine/uk/home/sus tainable-development-goals.html (data zvernennia: 07.10.2021) (in Ukrainian).

Tsymbaliuk, I. O. (2019). Osoblyvosti funktsionuvannia podatkovoi systemy Ukrainy ta otsinka yii fiskalnoi efektyvnosti. Ekonomichnyi chasopys Skhidnoievropeiskoho natsionalnoho universytetu imeni Lesi Ukrainky, 1(17), 106-115. doi: 10.29038/ 2411-4014-2019-01-106-115 (in Ukrainian).

Tsymbaliuk, I.O., \& Rykovska, L.V. (2017). Teoretychnyi analiz sutnosti ta skladovykh definitsii "ahrarna sfera". Ekonomichnyi chasopys Skhidnoievropeiskoho natsionalnoho universytetu imeni Lesi Ukrainky, 4 (12), 13-19. doi: 10.29038/2411-4014-2017-04-13-19 (in Ukrainian).

Zahorskyi, V. S., \& Borshchuk, Ye. M. (2019). Teoretykoprykladni aspekty doslidzhennia staloho rozvytku silskykh terytorii Ukrainy. Efektyvnist derzhavnoho upravlinnia, 2(59), 13-28. doi: 10.33990/ 2070-4011.59.2019.178413 (in Ukrainian). 